\title{
PENINGKATAN RESPON KOGNITIF DAN SOSIAL MELALUI RATIONAL EMOTIVE BEHAVIOUR THERAPY PADA KLIEN PERILAKU KEKERASAN
}

\author{
Dewi Eka Putri ${ }^{1,2 *}$, Budi Anna Keliat ${ }^{3}$, Yusron Nasution ${ }^{4}$ \\ 1. Program Studi Ilmu Keperawatan Fakultas Kedokteran Universitas Andalas, Padang 25163, Indonesia \\ 2. Program Studi Magister Fakultas Ilmu Keperawatan Universitas Indonesia, Depok 16424, Indonesia \\ 3. Fakultas Ilmu Keperawatan Universitas Indonesia, Depok 16424, Indonesia \\ 4. Fakultas Kesehatan Masyarakat Universitas Indonesia, Depok 16424, Indonesia \\ *Email:dewi_adisifa@yahoo.com
}

\begin{abstract}
Abstrak
Perilaku kekerasan adalah respon kemarahan maladaptif dalam bentuk perilaku mencederai diri, orang lain dan lingkungan. Penelitian ini bertujuan mendapatkan gambaran Pengaruh Rational Emotive Behaviour Therapy (REBT). terhadap penurunan perilaku kekerasan. Desain penelitian ini adalah quasi experimental pre-post test with control group. Sampel penelitian adalah 53 klien skizoprenia paranoid dengan perilaku kekerasan, terdiri atas 25 kelompok intervensi dan 28 orang kelompok kontrol. Hasil penelitian menunjukkan peningkatan respon kognitif dan sosial serta penurunan respon emosi, perilaku, dan fisiologis secara bermakna $(\mathrm{p} \leq 0,05)$ pada klien yang mendapatkan REBT. REBT direkomendasikan untuk diterapkan pada klien perilaku kekerasan bersama dengan tindakan keperawatan generalis.
\end{abstract}

Kata Kunci: perilaku kekerasan, rational emotive behaviour therapy

\section{Abstract}

Violent behaviour is a maladaptive anger response, which is shown by people whom treated themselves, others and the environment. The study aimed to explain the effect rational emotive behavioural therapy (REBT) in reducing violent behavioural. This research design was quasi-experimental using pre-post tests with control group. The samples of this research were 53 clients with paranoid schizophrenia who showed violent behavior, consisted of 25 clients as intervention group and 28 clients in control group. The Results showed significant increased cognitive as well as social responses and reduced emotional behavioural and physiological responses $(p \leq 0.05)$ on the group who get $R E B T$. REBT is recommended to be given to clients with violent behaviour together with general nursing inverventiont.

Keywords: violent behaviour, rational emotive behavior therapy

\section{Pendahuluan}

Kesehatan jiwa merupakan suatu kondisi sehat emosional, psikologis, dan sosial yang terlihat dari hubungan interpersonal yang memuaskan, perilaku dan koping yang efektif, konsep diri yang positif, dan kestabilan emosional (Johnson, 1997, dalam Videbeck, 2008). Di Indonesia, jumlah penderita masalah kesehatan jiwa cukup tinggi dan cenderung meningkat dari tahun ke tahun dan hampir di seluruh bagian dari wilayah Indonesia dalam beberapa dekade ini, populasi mengalami masa sulit karena konflik, kemiskinan maupun bencana alam. Berdasarkan hasil riset kesehatan dasar (Depkes, 2008) yang dilakukan Badan Penelitian Pengembangan Kesehatan Departemen Kesehatan menunjukkan prevalensi gangguan jiwa berat di Indonesia sebesar 4,6 permil, dengan kata lain dari 1000 penduduk Indonesia empat sampai lima diantaranya menderita gangguan jiwa berat.

Gangguan jiwa merupakan respon maladaptif individu berupa perubahan fungsi psikologis atau perilaku yang tidak sesuai dengan norma lokal dan budaya setempat yang menyebabkan timbulnya penderitaan dan hambatan dalam melaksanakan peran sosialnya. Skizoprenia merupakan salah satu diagnosa medis dari gangguan jiwa yang paling banyak ditemukan dan merupakan gangguan jiwa berat. Menurut data statistik direktorat kesehatan jiwa, pasien gangguan jiwa paling besar adalah skizofrenia, yaitu sebesar 70\% (Depkes, 2008). 
Perilaku kekerasan adalah suatu bentuk perilaku untuk melukai atau mencederai diri sendiri, orang lain, lingkungan secara verbal atau fisik (Stuart \& Laraia, 2005; 2009). Menurut Sulistyowati (2009), terapi musik dapat menurunkan perilaku kekerasan yang diketahui dari respon fisik, respon kognitif, respon perilaku, dan respon sosial klien. Menurut Stuart dan Laraia (2005) adalah terapi asertif, time outs, dan token economy.

Menurut Wahyuningsih (2009), perilaku kekerasan pada kelompok yang mendapat terapi generalis dan assertive training menurun secara bermakna pada respon fisik, respon kognitif, respon perilaku, dan respon sosial klien. Menurut Fauziah (2009), terapi perilaku kognitif dapat meningkatkan kemampuan kognitif dan perilaku klien skizoprenia dengan perilaku kekerasan. Respon kognitif merupakan hasil penilaian terhadap kejadian yang menekan, pilihan koping yang digunakan, reaksi emosional, fisiologis, perilaku, dan sosial individu (Stuart \& Laraia, 2005).

Berdasarkan teori tersebut maka perlu adanya intervensi pada klien dengan perilaku kekerasan yang mengarah kepada fisik, afektif (emosi), kognitif, fisiologis, perilaku, dan sosial. Terapi Asssertiveness Trainning, terapi musik, dan terapi perilaku kognitif belum mengarahkan intervensi secara langsung pada emosi klien dengan perilaku kekerasan. Adapun terapi yang dapat dilakukan untuk itu adalah $R E B T$.

\section{Rational Emotive Behaviour Therapy (REBT)} ditemukan oleh Albert Ellis. REBT adalah suatu metode untuk memahami dan mengatasi masalah emosi dan perilaku. Tujuan umum REBT adalah untuk mengurangi keyakinan tidak rasional dan menguatkan keyakinan rasional yang dapat efektif pada anak dan dewasa yang marah dan agresif melalui pembelajaran dan latihan kognitif, emosi dan perilaku. Berdasarkan penelitian Rieckert dan Moller (2000), terapi REBT secara signifikan dapat mengurangi depresi, kecemasan, kemarahan, perasaan bersalah, dan harga diri yang rendah. Penelitian keperawatan di Indonesia mengenai pengaruh REBT terhadap klien dengan perilaku kekerasan belum diketahui.

Berdasarkan uraian tersebut peneliti tertarik untuk menerapkan Rational Emotive Behaviour Therapy (REBT) pada klien dengan perilaku kekerasan di Rumah Sakit X Bogor. Perilaku kekerasan adalah urutan lima besar dari masalah keperawatan yang ditemukan di RS X Bogor yaitu halusinasi sebesar $26,24 \%$, defisit perawatan diri $19,15 \%$, isolasi sosial 16,31\%, HDR 13\%, dan PK 10,64\% (Data Aplikasi 2 \& Residensi 2 Keperawatan Jiwa). Oleh karena itu, perlu dilakukannya penelitian tentang pengaruh REBT terhadap penurunan perilaku kekerasan.

\section{Metode}

Penelitian ini adalah penelitian quasi experimental dengan metode kuantitatif dengan menggunakan desain penelitian quasi experimental pre-post tests with control group dengan intervensi REBT. Teknik pengambilan sampel secara consecutive sampling. Tujuan penelitian ini dilakukan untuk mengetahui perubahan perilaku pada klien dengan perilaku kekerasan baik secara kognitif, afektif (emosi), perilaku, sosial, dan fisiologis sebelum dan sesudah diberi intervensi berupa pemberian terapi REBT. Pada penelitian ini responden berjumlah 53 orang yang terdiri atas 28 orang pada kelompok kontrol dan 25 orang pada kelompok intervensi. Hal ini disebabkan 3 orang dari kelompok intervensi drop out. Analisis statistik yang dipergunakan adalah univariat, bivariat, dan multivariat dengan analisis dependent dan independent sample t-test, Chisquare, serta regresi linier ganda dengan tampilan dalam bentuk tabel dan distribusi frekuensi.

\section{Hasil}

\section{Karakteristik Responden}

Berdasarkan uraian hasil analisis karakteristik pada klien perilaku kekerasan (PK) dalam penelitian ini rerata berusia 35,02 tahun, termuda 19 tahun dan tertua 56 tahun, lebih banyak perempuan $(50,9 \%)$, 
Tabel 1. Perubahan Respon Perilaku Kekerasan pada Klien PK Sebelum dan Sesudah Pelaksanaan REBT pada Kelompok Intervensi

\begin{tabular}{|c|c|c|c|c|c|c|}
\hline Respon PK & $\begin{array}{l}\text { Pelaksanaan } \\
\text { REBT }\end{array}$ & $\mathbf{n}$ & Mean & SD & $\mathbf{S E}$ & $\mathbf{p}$ \\
\hline \multirow[t]{3}{*}{ Respon Kognitif } & Sebelum & 25 & 18,88 & 2,86 & 0,57 & 0,000 \\
\hline & Sesudah & 25 & 22,58 & 3,69 & 0,58 & \\
\hline & Selisih & & 3,80 & 0,83 & & \\
\hline \multirow[t]{3}{*}{ Respon Emosi } & Sebelum & 25 & 17,12 & 3,53 & 0,71 & 0,001 \\
\hline & Sesudah & 25 & 14,20 & 2,77 & 0,55 & \\
\hline & Selisih & & 2,92 & 0,76 & & \\
\hline \multirow[t]{3}{*}{ Respon Perilaku } & Sebelum & 25 & 13,00 & 2,02 & 0,40 & 0,000 \\
\hline & Sesudah & 25 & 10,68 & 1,82 & 0,36 & \\
\hline & Selisih & & 2,32 & 0,2 & & \\
\hline \multirow[t]{3}{*}{ Respon Sosial } & Sebelum & 25 & 14,24 & 1,88 & 0,38 & 0,002 \\
\hline & Sesudah & 25 & 15,84 & 1,57 & 0,15 & \\
\hline & Selisih & & 1,6 & 0,31 & & \\
\hline \multirow[t]{3}{*}{ Respon Fisiologis } & Sebelum & 25 & 9,04 & 1,31 & 0,26 & 0,000 \\
\hline & Sesudah & 25 & 6,48 & 0,59 & 0,12 & \\
\hline & Selisih & & 2,56 & 0,72 & & \\
\hline
\end{tabular}

sebagian besar tidak bekerja $(56,6 \%)$, memiliki jenjang pendidikan SD dan SMP $(60,4 \%)$. Serta, responden dengan adanya riwayat gangguan jiwa $(77,4 \%)$ dan frekuensi dirawat di rumah sakit 2 kali atau lebih $(77,4 \%)$.

\section{Respon Perilaku Kekerasan pada Klien PK}

Analisis respon-respon perilaku kekerasan terdiri atas; kognitif, emosi, perilaku, sosial, dan fisiologis pada klien PK. Berdasar kuesioner pada penelitian rentang respon kognitif adalah minimal 8 dan maksimal 32 (rendah 8 - 16; sedang 17 - 18; tinggi 19 - 32). Ini berarti respon kognitif pada klien PK semakin meningkat menunjukkan kognitif yang semakin baik. Hasil analisis respon kognitif adalah 18,48 dengan nilai minimal 13 dan maksimal 26, dapat disimpulkan bahwa rata-rata respon kognitif klien PK sebelum dilakukan terapi REBT adalah sedang.
Berdasar kuesioner pada penelitian rentang respon emosi adalah minimal 7 dan maksimal 28 (rendah 7 - 15; sedang $16-17$; tinggi $18-28$ ). Respon emosi klien PK semakin menurun menunjukkan emosi yang semakin baik. Hasil analisis rerata respon emosi sebelum dilakukan REBT yaitu 17,19 dengan nilai minimal 12 dan maksimal 26. Maka dapat disimpulkan rerata respon emosi klien PK sebelum dilakukan terapi REBT adalah sedang.

Berdasarkan kuesioner pada penelitian ini rentang respon perilaku adalah minimal 5 dan maksimal 20 (rendah 5-11; sedang 12 - 14; tinggi $15-20$ ). Respon perilaku pada klien PK semakin menurun menunjukkan perilaku yang semakin baik. Hasil analisis respon perilaku. Rerata respon perilaku sebelum dilakukan REBT adalah 13,25 dengan nilai minimal 8 dan nilai maksimal 17. Maka dapat disimpulkan bahwa rerata respon perilaku klien PK sebelum dilakukan terapi REBT adalah sedang. 
Berdasarkan kuesioner pada penelitian ini rentang respon sosial adalah minimal 6 dan maksimal 24 (rendah 6-12; sedang 13 - 14; tinggi 15-24). Respon sosial pada klien PK semakin meningkat menunjukkan sosial yang semakin baik. Hasil analisis rerata respon sosialnya sebelum dilakukan REBT adalah 13,77 dengan nilai minimal 10 dan nilai maksimal 19. Maka dapat disimpulkan bahwa rata-rata respon sosial klien PK sebelum dilakukan terapi REBT adalah sedang.

Berdasarkan kuesioner pada penelitian ini rentang respon fisiologis adalah minimal 6 dan maksimal 12 (rendah $6-8$; sedang $8-9$; tinggi $10-24$ ). Respon fisiologis pada klien PK semakin menurun menunjukkan fisiologis yang semakin baik. Hasil analisis rerata respon fisiologis sebelum dilakukan REBT adalah 9,16 dengan nilai minimal 6 dan nilai maksimal 13. Hasil dapat disimpulkan bahwa rerata respon fisiologis klien PK sebelum dilakukan terapi REBT adalah sedang.

\section{Perubahan Respon Perilaku Kekerasan Sebelum dan Sesudah Diberikannya REBT}

Berdasarkan uji statistik terdapat perubahan yang bermakna sesudah mendapatkan REBT terhadap respon PK. Respon kognitif klien meningkat secara bermakna sebesar $3,80(p=0,000 ; \alpha=0,05)$, respon emosi klien menurun secara bermakna sebesar 2,92 $(p=0,001 ; \alpha=0,05)$, respon perilaku klien menurun secara bermakna sebesar 2,32 $(p=0,000 ; \alpha=0,05)$, respon sosial klien meningkat secara bermakna sebesar $1,6(p=0,002 ; \alpha=0,05)$ dan respon fisiologis klien menurun secara bermakna sebesar $2,56(p=0,000 ; \alpha=0,05)$ (lihat pada tabel 1).

Tabel 2 menunjukkan uji statistik yang dilakukan pada kelompok kontrol sebelum dan sesudah REBT diberikan tidak terdapat perubahan yang bermakna pada klien dengan PK yang tidak mendapat REBT. Respon kognitif meningkat sebesar $0,47(p=0,613$; $\alpha=0,05)$, respon emosi menurun sebesar $0,36(\mathrm{p}=$ $0,514 ; \alpha=0,05)$, respon perilaku sebesar $0,14(\mathrm{p}=$ $0,718 ; \alpha=0,05)$, respon sosial meningkat sebesar $0,25(\mathrm{p}=0,677 ; \alpha=0,05)$, dan respon fisiologis menurun sebesar $0,43(p=0,184 ; \alpha=0,05)$.

\section{Perbedaan Respon Perilaku Kekerasan setelah Dilakukan REBT pada Kelompok Intervensi dan Kontrol}

Hasil analisis menunjukkan bahwa respon kognitif, emosi, perilaku, sosial, dan fisiologis pada klien PK yang mendapat REBT lebih baik secara bermakna dibandingkan dengan klien PK yang tidak mendapatkan REBT. Hal ini dapat dilihat dari tabel 3 .

\section{Perbedaan Selisih Perubahan Respon-Respon Perilaku Kekerasan Sebelum dan Setelah Terapi pada Kelompok Intervensi dan Kontrol}

Hasil analisis perbedaan selisih perubahan rerata respon-respon perilaku kekerasan antara klien yang mendapat REBT dan yang tidak mendapat REBT ada perbedaan yang bermakna $(\mathrm{p} \leq 0,05)$ yaitu selisih perubahan respon kognitif $\mathrm{PK}$ antara yang mendapat REBT dan yang tidak mendapat REBT ada perbedaan yang bermakna $(p=0,023 ; \alpha=0,05)$. Selisih perubahan respon emosi PK antara yang mendapat REBT dan yang tidak mendapat REBT ada perbedaan yang bermakna $(p=0,009 ; \alpha=0,05)$.

Selisih perubahan respon perilaku PK antara yang mendapat REBT dan yang tidak mendapat REBT ada perbedaan yang bermakna $(p=0,000 ; \alpha=0,05)$. Selisih perubahan respon sosial PK antara yang mendapat REBT dan yang tidak mendapat REBT tidak ada perbedaan yang bermakna $(p=0,076 ; \alpha=$ 0,05 ). Selisih perubahan respon fisiologis $\mathrm{PK}$ antara yang mendapat REBT dan yang tidak mendapat REBT ada perbedaan yang bermakna $(p=0,000$; $\alpha=0,05)$.

\section{Faktor yang Berkontribusi terhadap Respon Perilaku Kekerasan pada Klien PK}

Hasil analisis menunjukkan bahwa ada hubungan yang bermakna antara terapi REBT dengan respon PK (kognitif, emosi, perilaku, sosial, dan fisiologis) $(\mathrm{p} \leq 0,05)$. Sedangkan analisis karakteristik klien PK (usia, jenis kelamin, pendidikan, pekerjaan, riwayat gangguan jiwa, dan frekuensi dirawat) menunjukkan tidak ada hubungan bermakna antara karakteristik klien dengan respon PK (kognitif, 
Tabel 2. Perubahan Respon-Respon Perilaku Kekerasan pada klien PK Sebelum dan Sesudah Pelaksanaan REBT pada Kelompok Kontrol

\begin{tabular}{|c|c|c|c|c|c|c|}
\hline Respon PK & $\begin{array}{l}\text { Pelaksanaan } \\
\text { REBT } \\
\end{array}$ & $\mathbf{n}$ & Mean & SD & $\mathbf{S E}$ & $\mathbf{p}$ \\
\hline \multirow[t]{3}{*}{ Respon Kognitif } & Sebelum & 28 & 18,07 & 3,49 & 0,66 & 0,613 \\
\hline & Sesudah & 28 & 18,54 & 3,21 & 0,61 & \\
\hline & Selisih & & 0,47 & 0,28 & & \\
\hline \multirow[t]{3}{*}{ Respon Emosi } & Sebelum & 28 & 17,25 & 3,01 & 0,57 & 0,514 \\
\hline & Sesudah & 28 & 16,89 & 2,91 & 0,55 & \\
\hline & Selisih & & 0,36 & 0,1 & & \\
\hline \multirow[t]{3}{*}{ Respon Perilaku } & Sebelum & 28 & 13,50 & 1,88 & 0,35 & 0,718 \\
\hline & Sesudah & 28 & 13,36 & 1,68 & 0,32 & \\
\hline & Selisih & & 0,14 & 0,2 & & \\
\hline \multirow[t]{3}{*}{ Respon Sosial } & Sebelum & 28 & 13,29 & 2,42 & 0,46 & 0,667 \\
\hline & Sesudah & 28 & 13,54 & 2,15 & 0,41 & \\
\hline & Selisih & & 0,25 & 0,27 & & \\
\hline \multirow[t]{3}{*}{ Respon Fisiologis } & Sebelum & 28 & 9,29 & 1,15 & 0,22 & 0,184 \\
\hline & Sesudah & 28 & 8,86 & 1,08 & 0,20 & \\
\hline & Selisih & & 0,43 & 0,07 & & \\
\hline
\end{tabular}

emosi, perilaku, sosial, dan fisiologis) ( $\mathrm{p} \geq 0,05)$, kecuali untuk frekuensi dirawat ditemukan adanya hubungan denga nrespon sosial klien $(\mathrm{p} \leq 0,05)$.

\section{Pembahasan}

\section{Pengaruh REBT terhadap Respon Perilaku Kekerasan pada Klien PK}

Pada klien yang mendapatkan terapi psikososial REBT ditemukan peningkatan secara bermakna pada respon kognitif, ini berarti REBT berpengaruh terhadap peningkatan respon kognitif klien PK sehingga pengetahuan klien meningkat tentang masalah perilaku kekerasan yang dialami sebagai perilaku maladaptif yang dapat mencelakakan dirinya, orang lain, dan lingkungan. Penelitian ini sesuai dengan penelitian Rieckert dan Moller (2000) menyatakan terapi REBT secara bermakna dapat mengurangi kemarahan, perasaan bersalah, dan harga diri yang rendah. Melalui terapi REBT klien dilatih untuk dapat mengevaluasi diri sendiri dengan mengidentifikasi kejadian yang pernah dialami, pikiran-pikiran tidak rasional yang timbul berhubungan dengan kejadian, dan mempengaruhi perasaan (emosi) klien sehingga menghasilkan perilaku maladaptif yang tidak diinginkan.

Pada klien PK menunjukkan terdapat perbedaan penurunan respon emosi secara bermakna antara kelompok yang mendapatkan terapi REBT dan yang tidak mendapatkan REBT. Hal ini karena terapi REBT memberikan kesempatan pada klien untuk mengenali perasaan yang disebabkan oleh adanya pikiran tidak rasional terhadap setiap kejadian atau peristiwa yang membuat klien berperilaku kekerasan sehingga klien mengenali perasaan yang dapat menimbulkan perilaku maladaptif. REBT adalah metode untuk memahami dan mengatasi masalah emosi dan perilaku (Froggatt, 2005). 
Teori REBT menegaskan bahwa keyakinan yang tidak rasional akan membawa individu pada emosi dan perilaku negatif tidak sehat seperti perilaku amuk (agresif) dan rasa bersalah (Jensen, 2008). REBT baik diberikan pada klien PK karena di dalam materi REBT menjelaskan kepada klien tentang cara berpikir rasional, mengubah emosi yang mengganggu menjadi emosi menyenangkan sehingga klien dapat menyelesaikan masalah. Sesuai dengan konsep REBT bahwa emosi dan perilaku merupakan hasil dari proses pikir yang memungkinkan bagi manusia untuk memodifikasi, seperti proses untuk mencapai dengan cara yang berbeda dalam merasakan dan bertindak (Froggatt, 2005).

Hasil penelitian yang dilakukan terhadap klien PK memperlihatkan bahwa adanya penurunan yang bermakna pada respon perilaku antara kelompok yang mendapatkan dan yang tidak mendapatkan terapi REBT. Hal ini menunjukkan bahwa REBT memberikan pengaruh yang bermakna terhadap penurunan perilaku kekerasan pada klien. Berdasar literatur Albert Ellis (Corsini \& Wedding, 1989 dalam Parrott, \& Zeichner, 2003) berpendapat bahwa yang perlu diubah individu untuk mengatasi masalah emosi maupun perilakunya adalah adanya keyakinan tidak rasional yang dikembangkan oleh individu dan Albert Ellis mengembangkan sebuah terapi yang bernama REBT (Rational Emotive Behavioural Therapy).

Sunaryo (2004) menyatakan bahwa perubahan perilaku dipengaruhi beberapa hal yaitu kebutuhan, motivasi, sikap, dan kepercayaan. Dengan terbina saling percaya perawat dengan klien, dan adanya kebutuhan serta motivasi klien untuk merubah diri maka perilaku dapat diubah lebih cepat.

Berdasarkan hasil penelitian yang dilakukan pada klien PK ditemukan peningkatan secara bermakna pada respon sosial klien yang mendapatkan REBT. Hal ini berarti REBT berpengaruh secara bermakna dalam meningkatkan respon sosial klien PK. Menurut Boyd dan Nihart (1998), tanda dan gejala perilaku kekerasan secara sosial akan ditemukan penurunan interaksi sosial. Menurut Beck (1999), bahwa emosi marah sering merangsang kemarahan orang lain. Pengalaman marah dapat mengganggu hubungan interpersonal. Dengan diberikannya REBT, klien akan belajar untuk berpikir secara rasional dan berperilaku yang adaptif sehingga hubungan interpersonalnya dengan orang lain akan meningkat.

Pada klien yang mendapatkan terapi psikososial REBT ditemukan penurunan secara bermakna pada respon fisiologis. Hal ini berarti REBT berpengaruh terhadap penurunan respon fisiologis klien PK. Menurut Stuart dan Laraia (2009), bahwa perilaku kekerasan dapat dilihat dari wajah tegang, tidak bisa diam, mengepalkan atau memukulkan tangan, rahang mengencang, peningkatan pernafasan, dan kadang tiba-tiba seperti kataton.

Menurut Beck (1999) bahwa respons fisiologis marah timbul karena kegiatan sistem saraf otonom bereaksi terhadap sekresi epineprin, sehingga tekanan darah meningkat, frekuensi denyut jantung meningkat, wajah merah, pupil melebar, dan frekuensi pengeluaran urin meningkat. Dengan diberikan REBT pada klien maka klien akan belajar untuk berpikir rasional, mengontrol perasaannya, dan perilakunya sehingga sistem saraf otonom tidak bereaksi dan respon fisiologis menjadi turun mencapai batas normal.

\section{Faktor yang Berhubungan dengan Respon Perilaku Kekerasan}

Hasil penelitian ini menunjukkan bahwa usia, jenis kelamin, pendidikan, pekerjaan, riwayat gangguan jiwa, dan frekuensi dirawat tidak ada hubungan bermakna dengan respon perilaku kekerasan. Hal ini menunjukkan perubahan usia, jenis kelamin, pendidikan, pekerjaan, riwayat gangguan jiwa, dan frekuensi di rawat tidak diikuti oleh perubahan pada respon perilaku kekerasan (respon kognitif, emosi, perilaku, sosial, maupun fisiologis). Namun, khusus frekuensi dirawat ada hubungan bermakna dengan respon sosial. Hal ini berarti bila terjadi perubahan pada frekuensi dirawat maka akan terjadi pula berubahan pada respon sosial klien. 
Tabel 3. Respon Perilaku Kekerasan pada Klien PK setelah Dilakukan REBT

\begin{tabular}{|c|c|c|c|c|c|c|}
\hline Respon PK & Kelompok & $\mathbf{n}$ & Mean & SD & Min-Max & $\mathbf{p}$ \\
\hline \multirow[t]{2}{*}{ Respon Kognitif } & a. Intervensi & 25 & 22,68 & 2,90 & $18-31$ & 0,000 \\
\hline & b. Kontrol & 28 & 18,54 & 3,21 & $11-25$ & \\
\hline \multirow[t]{2}{*}{ Respon Emosi } & a. Intervensi & 25 & 14,20 & 2,39 & $8-19$ & 0,001 \\
\hline & b. Kontrol & 28 & 16,89 & 2,30 & $12-23$ & \\
\hline \multirow[t]{2}{*}{ Respon Perilaku } & a. Intervensi & 25 & 10,68 & 1,82 & $7-14$ & 0,000 \\
\hline & b. Kontrol & 28 & 13,36 & 1,68 & $10-16$ & \\
\hline \multirow[t]{2}{*}{ Respon Sosial } & a. Intervensi & 25 & 15,84 & 1,57 & $13-19$ & 0,000 \\
\hline & b. Kontrol & 28 & 13,54 & 2,15 & $8-19$ & \\
\hline \multirow[t]{2}{*}{ Respon Fisiologis } & a. Intervensi & 25 & 6,48 & 0,59 & $6-8$ & 0,000 \\
\hline & b. Kontrol & 28 & 8,86 & 1,08 & $6-10$ & \\
\hline
\end{tabular}

\section{Kesimpulan}

Karakterisitik 53 orang responden dalam penelitian ini rerata berusia 35 tahun dengan usia termuda 19 tahun dan tertua 56 tahun, lebih banyak perempuan $(50,9 \%)$, sebagian besar tidak bekerja $(56,6 \%)$, memiliki jenjang pendidikan SD dan SMP $(60,4 \%)$, dengan adanya riwayat gangguan jiwa $(77,4 \%)$ dan frekuensi dirawat di rumah sakit 2 kali atau lebih. Kemampuan klien mengontrol perilaku kekerasan diketahui dari respon PK klien yang meliputi respon kognitif, emosi, perilaku, sosial, dan fisiologis. Hasil penelitian menunjukkan ada perubahan yang bermakna pada respon klien PK antara sebelum mendapatkan REBT dengan setelah mendapatkan REBT. Perubahan yang terjadi adalah pada respon kognitif dan sosial terjadi peningkatan bermakna, sedangkan pada respon emosi, perilaku, dan fisiologis terjadi penurunan secara bermakna.

Hasil analisis juga menunjukkan bahwa respon kognitif, emosi, perilaku, sosial, dan fisiologis pada klien PK yang mendapat REBT lebih baik secara bermakna dibandingkan dengan klien PK yang tidak mendapatkan REBT. Ada pengaruh REBT terhadap kemampuan klien dalam mengontrol PK melalui respon kognitif, emosi, perilaku, sosial, dan fisiologisnya. Ada pengaruh frekuensi klien dirawat di rumah sakit dengan respon sosial klien PK. Hasil menunjukkan bahwa tidak ada pengaruh, usia, jenis kelamin, pekerjaan, riwayat gangguan jiwa, dan ferekuensi dirawat di rumah sakit dengan respon kognitif, emosi, perilaku, dan fisiologis klien PK.

Perawat jiwa di rumah sakit diharapkan selalu memotivasi klien dan mengevaluasi kemampuankemampuan yang telah dipelajari dan dimiliki klien sehingga latihan yang diberikan dapat membudaya. Pemberian terapi lanjutan dari terapi yang sesuai dengan SAK akan memberikan hasil yang lebih maksimal, seperti terapi generalis PK dan REBT pada klien PK. Hasil penelitian ini hendaknya digunakan sebagai evidence based dalam upaya mengembangkan terapi REBT pada individu dan kelompok dengan masalah keperawatan jiwa lainnya dan menjadi bagian dari kompetensi yang dimiliki oleh perawat spesialis (DN, AY, HP).

\section{Referensi}

Beck, A.T., (1999). Prisoners of hate: The cognitive basis of anger, hostility, \& violence. New York, NY: HarperCollins. 
Boyd, M.A., \& Nihart, M.A. (1998). Psychiatric nursing contemporary practice. USA: Lippincott Raven Publisher.

Depkes RI. (2008). Riset kesehatan dasar 2007. Diperoleh dari www.litbang.go.id.

Fauziah. (2009). Pengaruh terapi perilaku kognitif (TPK) pada klien skizoprenia dengan perilaku kekerasan di Rumah Sakit Marzoeki Mahdi Bogor (Tesis master, tidak dipublikasikan). Fakultas Ilmu Keperawatan Universitas Indonesia, Jakarta.

Froggatt, W. (2005). A brief introduction to rational emotive behaviour therapy (3rd Ed.). New Zealand, Stortford Lodge: Hastings.

Jensen, P.E. (2008). Evaluating the ABC models of rational emotive behaviour therapy theory: An analysis of the relationship between irrational thinking and guilt (Thesis, The Faculty of Department Psychology Villanova University). Faculty of Department Psychology Villanova University, United State. Diperoleh dari http:// ProQuest LLC.

Parrott, D.J., \& Zeichner, A. (2003). Effects of trait anger and negative attitudes towards women on physical assaults in dating relationships. Journal of Family Violence, 18 (5), 301-307.
Rieckert, J., \& Moller, A.T. (2000). Rational-emotive behaviour therapy in the treatment of adult victims of childhood sexual abuse. Journal of Rational Emotive \& Cognitif-Behaviour Therapy, 18 (2), 87-101. Doi: 10.1023/A:1007824719770.

Stuart, G.W., \& Laraia, M.T. (2009). Principles and practice of psychiatric nursing (7th Ed.). St. Louis: Mosby.

Stuart, G.W., \& Laraia, M.T. (2005). Principles and practice of psychiatric nursing (7th Ed.). St. Louis: Mosby.

Sulistyowati, C.E. (2009). Pengaruh terapi musik terhadap perubahan perilaku pada klien skizoprenia dengan perilaku kekerasan di Rumah Sakit Jiwa Daerah Surakarta (Tesis master, tidak dipublikasikan). Fakultas Ilmu Keperawatan Universitas Indonesia, Jakarta.

Sunaryo. (2004). Psikologi untuk keperawatan. Jakarta: EGC.

Wahyuningsih, D. (2009). Pengaruh assertiveness training terhadap perilaku kekerasan pada klien skizoprenia di RSUD Banyumas (Tesis master, tidak dipublikasikan). Fakultas Ilmu Keperawatan Universitas Indonesia, Jakarta. 